\title{
Study of the Microbiological Quality of Improved Spirulina Marketed in Chad
}

\author{
Abdelsalam Tidjani ${ }^{1 *}$, Abdelsalam Adoum Doutoum² ${ }^{2}$ Hamit Mahamat Alio ${ }^{1}$ and Mahamat Nour Aguid ${ }^{1}$ \\ ${ }^{1}$ Laboratoire de Recherches en Sciences des Aliments et Nutrition (LARSAN), Faculté des Sciences de la Santé Humaine (FSSH), Université de \\ N'Djamena-Tchad
}

${ }^{2}$ Institut National des Sciences et Techniques d'Abéché (INSTA), Tchad

Received: November 6, 2017; Published: January 19, 2018

*Corresponding author: Abdelsalam Tidjani,Laboratoire de Recherches en Sciences des Aliments et Nutrition (LARSAN), Faculté des Sciences de la Santé Humaine (FSSH), Université de N’Djamena, Tchad, Email: abdelti@yahoo.fr, abdelti@gmail.com

\begin{abstract}
Food and nutrition security is an important determinant in any development process. One of the ways to improve food security is the use of spirulina commonly known as "dihé" in Chad. It is a microalga very rich in protein, vitamins, and trace elements. This commodity exists in large quantities in Lake Chad. However, few studies have investigated its' microbiological quality. Yet the knowledge of its safety is necessary for a healthy production and consumption of the product. The purpose of this study is to assess the hygienic quality of improved "dihé" spirulina sold at the local market in the city of Bol (Lake Chad). The aim is to carry out laboratory analyzes to evaluate the microbiological quality of spirulina so as to promote this product and use it as a solution to malnutrition, especially for children. To carry out this work, 30 units of "dihé", ie 10 representative samples were taken and analyzed at the Laboratory of Research in Food and Nutrition Sciences (LARSAN) of the University of N'Djamena. The search for germs was made by standard methods of routine of the French Association of Normalization (AFNOR). This study shows that the products analyzed are of acceptable microbiological quality. But, the promotion of this commodity by raising awareness among producers, consumers and decision-makers is necessary to improve the nutritional situation in the sub-region.
\end{abstract}

Keywords: Spirulina; Bacteria; Quality; Microbiology; Malnutrition;

\section{Introduction}

Food safety is a real public health problem. Spirulina (Spirulina platensis) is an alga that grows naturally in the regions of Lake Chad and Kanem [1]. In countries where malnutrition is endemic, spirulina may be a possible solution to fight malnutrition. Many studies have shown that spirulina is nutritionally rich in protein [2], fatty acids [3], beta-carotenes [4], vitamins [5,6] and minerals [7,8]. Other studies [9-11] mentioned the nutritional value of Spirulina.

The role of spirulina in the prevention of many diseases such as cancer, heart disease and aging has also been mentioned [12,13]. According to Halawlaw [14], the production of Spirulina is very simple and it can be mastered by any peasant which is very interesting for developing countries. It should be mentioned, however, that few studies have been conducted in Chad to ascertain the microbiological quality of this commodity. Knowing that food safety has become a real health problem, it seems important to conduct this study to identify germs that could contaminate spirulina. It should be noted that several scientific studies [15-18] have mentioned deficiencies in the microbiological quality of foods. The present work will therefore contribute to the analysis of Lake Chad spirulina to promote its use with a view to improving the nutritional situation in Chad.

\section{Materials and methods}

Spirulina samples were analyzed at the Food Sciences and Nutrition Research Laboratory (LARSAN) of the University of N'Djamena. The biological material consists of ten representative samples of improved spirulina sold in powder form packaged in plastic bags, purchased at the local Bol market. Sampling and transport equipment consists of aluminum foil, poly bags, tongs and a cooler. The technical equipment consists of an electronic scale (Mark 8055, Chimica amnia), a freezer oven, and incubators at $30^{\circ} \mathrm{C}, 37^{\circ} \mathrm{C}$, and 44 ${ }^{\circ} \mathrm{C}$. An autoclave (Leuqueux Paris), spatulas and laboratory glassware. Analysis method In total we have collected 30 units or ten samples of "dihé" (Spirulina platensis) at the Bol market. These samples are obtained using quartering techniques. Samples of $100 \mathrm{~g}$ of "dihé" were made under sterile conditions, 
packaged in sterilized aluminum papers and introduced into the cooler and then transported to the Laboratory (LARSAN) in N'Djamena for analysis. The operations in the laboratory were made under conditions of total asepsis. We used the methods described by the French Association for Standardization (AFNOR) for the microbiological analysis of samples [19]. For the preliminary, a distribution of the samples was made as well as its homogenization. Using a spatula, $10 \mathrm{~g}$ of each sample are suspended in $90 \mathrm{ml}$ of Tryptone-Salt solution thus obtaining mother suspensions. After homogenizing the solution, 45 minutes were given to revivification at laboratory temperature. Each stock solution is then subjected to a series of decimal dilutions by placing $1 \mathrm{ml}$ of the stock solution or previous dilutions in $9 \mathrm{ml}$ of Tryptone - salt. We used the in-bulk seeding technique for germ search and enumeration. With a pipette, $1 \mathrm{ml}$ of the stock solution or one of its decimal dilutions are put in Petri dishes. We then poured $20 \mathrm{ml}$ of appropriate culture medium and incubated (Table 1). Supports for standards methods are used (AFNOR, 2002). Searched germs are total mesophilic flora (Total bacteria) $\left(30^{\circ} \mathrm{C}\right)$ (NF.V08-051), Total coliforms $30^{\circ} \mathrm{C}$ (NF.V08-050), Thermotolerant coliforms and E. coli (NF ISO 4831), Anaerobic Sulfite-reducing $44{ }^{\circ} \mathrm{C}$ (NF.V08-061), S. aureus $37{ }^{\circ} \mathrm{C}$ (NF ISO 6888-1) and salmonella (AFNOR.V08-052). Also, molds and yeasts (ISO 21527) were the subject of research. The thus seeded dishes are inverted and incubated at the recommended temperatures and times required to obtain typical colonies. The reading was done by the colony counter according to the culture characteristics of each type of seed.

Interpretation of the results is done according to the criteria established by the French Association of Normalization (1998). Results are expressed in Colony Forming Units per gram of "dihé" analyzed (CFU/g).

\section{Artisanal production of "dihé" improved}

Artisanal production of the improved "dihé" is done according to several main steps. Women enter the water and pick up the "dihe" with plastic cups or buckets. The "dihé" is transferred to a sieve of $5 \mathrm{~mm}$ mesh which retains the impurities. The product is then recovered in a second $600 \mu \mathrm{m}$ mesh screen which retains spirulina and allows a large part of the water to pass through. The solution is then recovered in a cloth and then pressed by hand to evacuate a large part of the water. The latter is put in an extruder, after the extrusion is obtained "dihe" in the form of spaghetti or cake that is

Table 1: Microbiological analyzes of samples.

\begin{tabular}{|c|c|c|c|c|c|c|c|c|}
\hline Samples & GF & TC & TTC & SRA & M & S.aureus & $\begin{array}{c}\text { Salmonella } \\
\text { sp }\end{array}$ \\
\hline S1 & 310 & 0 & 0 & 0 & 0 & 0 \\
\hline S2 & 518 & 0 & 0 & 0 & 0 & 0 \\
\hline S3 & 25 & 0 & 0 & 0 & 0 & 0 \\
\hline S4 & $3.7 \times 10^{5}$ & 0 & 0 & 0 & 0 & 0 \\
\hline
\end{tabular}


Nutrition \& Food Science International Journal

\begin{tabular}{|c|c|c|c|c|c|c|c|c|}
\hline S5 & 88 & 0 & 0 & 0 & 0 & 0 & 0 & 0 \\
\hline S6 & 203 & 0 & 0 & 0 & 3 & 0 & 0 & 0 \\
\hline S7 & 106 & 0 & 0 & 0 & 0 & 0 & 0 & 0 \\
\hline S8 & 330 & 0 & 0 & 0 & 0 & 0 & 0 & 0 \\
\hline S9 & 116 & 0 & 0 & 0 & 0 & 0 & 0 & 0 \\
\hline S10 & 245 & 0 & 0 & 0 & 0 & 0 & 0 & 0 \\
\hline AFNOR Criteria $*$ & $3 \times 10^{5} \mathrm{CFU} / \mathrm{g}$ & $10^{3} \mathrm{CFU} / \mathrm{g}$ & $10 \mathrm{CFU} / \mathrm{g}$ & $30 \mathrm{CFU} / \mathrm{g}$ & $\mathrm{NC}$ & $\mathrm{NC}$ & $10^{2} \mathrm{CFU} / \mathrm{g}$ & $\mathrm{Abs} / 25$ \\
\hline
\end{tabular}

Note: S: Samples; CFU: Colony Unit Unit (CFU) per gram; NC: Not considered; GF: Global flora; TC: Total coliform; TTC: Thermotolerant coliform; SRA: Sulphito-reducing anaerobes; M: Mold; Y: Yeast; Abs: Absence per 25g

${ }^{*}$ Criteria of the French Association of Normalization.

\section{Distribution of samples according to the sites}

Our samples taken from three different "dihé" production sites including Artomossi, Brandji and Kadassara Table 2.

A sample of Artomossi contains more total germs than the reference; another sample of the same site contains molds.
Samples from the other two sites do not contain mold, total germ numbers are consistent.

The results show that $90 \%$ of the samples analyzed are satisfactory compared to the total mesophilic flora. Samples do not contain $S$. aureus or salmonella.

Table 2: Assessment of analyzed samples according to the sites.

\begin{tabular}{|c|c|c|c|}
\hline Origin & $\begin{array}{c}\text { Number of } \\
\text { samples }\end{array}$ & $\begin{array}{c}\text { Number of samples Containing the } \\
\text { total germs }>\text { at the limit (CFU/g) }\end{array}$ & $\begin{array}{c}\text { Number of samples } \\
\text { Containing molds }\end{array}$ \\
\hline Artomossi & 3 & 1 & 1 \\
\hline Brandji & 3 & 0 & 0 \\
\hline Kadassara & 4 & 0 & 0 \\
\hline
\end{tabular}

Notes: SRA = Sulphito-reducing anaerobes; M: Mold; Y: Yeast; NC: Not considered

$\mathrm{M}^{*}$ corresponds to the threshold value; $\mathrm{M}^{* *}$ : symbolizes the acceptability threshold.

Table 3: Overall assessment of the results.

\begin{tabular}{|c|c|c|c|c|c|c|}
\hline \multirow[t]{2}{*}{ Searched germs } & \multicolumn{3}{|c|}{ Extreme values } & \multicolumn{3}{|c|}{ Hygienic quality (\%) } \\
\hline & & $\mathbf{m}^{*}$ & $\mathbf{M}^{* *}$ & Satisfactory & Acceptable & Unsatisfactory \\
\hline Total germs & $25-3.7 \times 10^{5}$ & $3 \times 10^{5}$ & $3 \times 10^{6}$ & 90 & 10 & 0 \\
\hline Total coliforms & 0 & $10^{3}$ & $10^{4}$ & 100 & 0 & 0 \\
\hline $\begin{array}{l}\text { Thermotolerant } \\
\text { coilforms }\end{array}$ & 0 & 10 & 100 & 100 & 0 & 0 \\
\hline SRA & 0 & 30 & 300 & 100 & 0 & 0 \\
\hline S. aureus & 0 & $10^{2}$ & 100 & 100 & 0 & 0 \\
\hline Salmonella $s p$ & 0 & Abs $/ 25$ & NA & 100 & 0 & 0 \\
\hline Yeasts and Molds & $0-3$ & $\mathrm{NC}$ & $\mathrm{NC}$ & ---- & ---- & --- \\
\hline
\end{tabular}

\section{Discussion}

Spirulina very rich in protein is presented as an original and interesting element for the response of malnutrition in developing countries where nutritional deficiencies are sources of morbidity and mortality. It is a traditional food since ancient times, cultivated and consumed today all over the world for its high nutritional quality; spirulina is a leader in the fight against malnutrition in the North (over-nutrition) as in the South (undernutrition) [20].

Samples of "dihé" analyzed showed varied results. The presence of total mesophilic flora or total germs is reported in all samples collected and analyzed. Wu and Pond [21] found
$3 \times 10^{4}$ to $6 \times 10^{5} \mathrm{CFU} / \mathrm{g}$ in the liquid medium. After harvesting and drying, spirulina contained only $10^{3}-10^{6}$ revivifiable microorganisms per gram. This number decreases steadily with the storage time especially due to drying. The maximum number of total mesophilic organisms found in one of our samples, however, is higher than the threshold of acceptability set for dehydrated soups, which is $3 \times 10^{5} \mathrm{CFU} / \mathrm{g}$. This contamination is due to the non respect of the rules of hygiene during the harvest, the transformation and the conservation of Spirulina. Other studies [22] carried out on the Impact of packaging and shelf life on the nutritional and microbiological quality of Moringa and spirulina-enriched sorghum biscuits, have revealed a fairly high concentration of mesophilic flora, 
but emphasizes that this is not attributable to the conditions of conservation but rather to post-production contaminations of biscuits enriched with Moringa and Spirulina.

In our series of analyzes, coliforms were absent in the analyzed samples. According to Karar et al. [23], the absence of faecal coliforms is the result of the absence of faeces in the traditional and improved "dihé". These values are in line with international standards. Samples do not contain S. aureus or Salmonella sp. These results are similar to those obtained in studies conducted on spirulines produced industrially in the USA and Japan, which demonstrated the total absence of pathogens such as Salmonella, Shigellae or Staphylococci in their samples [24].

Studies by Vermorrel show that the microflora associated with spirulina cultures is generally rare and non-pathogenic. Also the high alkalinity of the culture medium is an excellent barrier against most contaminations of both bacteria and yeast [25]. The absence of coliforms in the samples attests to a good hygienic quality of the raw material [19]. In the same way the producers were trained by the pilot project "dihé" of FAO on the good practices of handling and manufacture of Spirulina. Study also showed the presence of molds in one sample. The undesirable presence of mold changes the appearance of food products, due in particular to the production of pigments, such as melanin, a dark pigment [26]. The metabolites produced by these fungi during their growth on the food are also major elements in the deterioration of foodstuffs. Foods are generally very favorable environments for their development. It is really from 1960, that one became aware that the molds could produce significant toxins [27]. But in the case of this study on the microbiological quality of Spirulina, the number of molds is not as important. Their presence is due either to a deficiency in drying or to a poor storage condition. In general, all samples conform to the standards except sample No. 7, whose total seed value slightly exceeds the acceptability threshold, but compliant the standards if we consider the analytical variability associated with the search for this germ.

\section{Conclusion}

This study has allowed us to note that the "dihé" produced of Lake Chad region is of acceptable hygienic quality. Information regarding Spirulina especially his interest in the fight against malnutrition were capitalized. Faced with the major challenges of the moment, it is necessary to look for effective and economically adapted solutions for our populations. Spirulina, because of its remarkable qualities, its ease of cultivation and its safety, can be an effective and sustainable solution to the problems of malnutrition that continue to arise acutely in developing countries. The results concluded the absence of the pathogens sought thereby showing the safety of this commodity as regards its consumption. However, the remarkable presence of total mesophilic organisms is apparent. A sensitization of producers and processors to good hygiene practices would be necessary for healthy consumption.

\section{References}

1. Sorto M (2003) Utilisation et consommation de la spiruline au Tchad. Institut Tchadien de Recherche Agronomique pour le Développement (ITRAD). In Actes du 2ème Atelier International/ $2^{\text {nd }}$ International Workshop. Voies alimentaires d'amélioration des situations nutritionnelles. Food based approaches for a healthy nutrition Ouagadougou (23-28): 850.

2. Bujard E, Braco U, Mauron J, Mottu F, Nabholz A, et al. (1970) Composition and nutritive value of blue-green algae (Spirulina) and their possible use in Food Formulations 3rd International Congress of Food Science and Technology, Washington, USA.

3. Hwang D (1989) Essential fatty acids and immune response. FASEB] 3(9): 2052-2061.

4. CarerI M, Furlattini L, Mangia A, Musci M, Anklam E, et al. (2001) Supercritical fluid extraction for liquid chromatographic determination of carotenoîds Spirulina pacifica algae: a chemo metric approach. J chromatography A 912(1): 61-71.

5. Han R (1995) Vitamin B12 under microalgae Spirulina platensis. FIT fûr LEBEN 1: 29.

6. Gomez-Coronado DJ, Ibanez E, Ruperez FJ, Barbas C (2004) Tocopherol measurement in edible products of vegetable origin. J Chromatogr A 1054(1-2): 227-233.

7. Puyfoulhoux G, Rouanet JM, Besancon P, Baroux B, Baccou JC, et al (2001) Iron availability from iron fortified Spirulina by an in vitro digestion/CaCO2 cell culture model. J Agric Food Chem 49(3): 16251629 .

8. Ribadeneira M, Garci P (2006) Comparative analysis of the use of $100 \%$ vegetable iron and iron sulfate as iron source for the treatment of ferriprive anemia A publier ; cité dans phytonutrition et environnement JM Robin

9. Jourdan JP (2006) Cultivez votre Spiruline. Manuel de culture artisanale pour la production de spiruline Antenna Technologie, Paris, France.

10. Tidjani A, Doutoum AA, Aguid MN, Bechir M (2013) Spirulina: An Effective Dietary Supplement for Malnourished Children in Development Country. Advances in Food Sciences and Nutrition, $\left(1^{\text {st }}\right.$ edn), Science and Education Development Institute, Nigeria/Queen's College of Food Technology \& Research Foundation Aurangabad, India, Chapter 8, pp. 113-127.

11. Charpy L, Langlade MJ, Alliod R (2008) La spiruline peut-elle être un atout pour la santé et le développement en Afrique? Institut de Recherche pour le Développement. UR 167 (CYROCO), p. 67.

12. Reddy CM, Bhat VB, Kiranmai G, Reddy MN, Reddanna P, et al. (2000) Selective inhibition of cyclooxygenase-2 by C-phycocyanin a biliprotein from Spirulina platensis. Biochem Biophys Res Commun 277(3): 599603

13. Girardin-Andréani C (2005) Spiruline: Système Sanguine, Système Immunitaire et Cancer, Phytotherapie 4(3): 158-161.

14. Yacoub Idriss H (2014) Spirulina microalga: A Food for future. Pinnacle Biotechnology 1(2).

15. Barro N, Bello AR, Itsiembou Y, Savadogo A, Ouattara CAT, et al. (2007) Street-vended Food improvement: Contamination Mecanism and Application of Food Safety ObjectiveStrategy: Critical review. Pakistan journal of nutrition 6(1): 1-10.

16. Abdelrahim AM, Tidjani A, Doutoum AA, Barro N, Traore AS (2012) Evaluation de la Qualité Microbiologique des Poissons Braisés et de leurs Assaisonnements Vendus dans les Rues de la Ville de Ouagadougou-Burkina Faso. Microbiol Hyg Alim 24(69): 47-54. 
17. Doutoum AA, Tidjani A, Abdelaziz AI, Tidjani SMT, Balde M, et al (2013) Identification of the Lactic Microorganism Responsible for Milk Coagulation in Abeche (Chad). African Journal of Food Science 7(5): 103-106.

18. Tidjani AA, Doutoum AA, Otchom BB, Bechir M, Chemi HD, et al. (2013) Assessment of Hygiene Practices and Identification of Critical Control Points Relating to the Production of Skewered Meat Sold in N'DjamenaChad. JFood Research 2(5).

19. Bourgeois CM, Leveau JY (1991) Technique d'analyse et contrôle dans les industries agroalimentaires. Contrôle microbiologique. 3(2 edn), Technique et documentation. Lavoisier, France, pp 454.

20. Anonyme, Témoignage (2015) La spiruline: De l'aliment ancestral à une aquaculture moderne. NATURE et PROGRÈS. avril-mai, pp. 102.

21. Wu JF, Pond WG (1981) Amino Acid Composition of Spirulina maxima, a blue-green Alga, Grown on the Effluent of Different Fermented Animal Wastes. Bull Environn Contam Toxicil 27(2): 151-159.

22. Laurencia T, Songré-Ouattara, Mahamadé Goubgou, Aly savadogo (2017) Impact of the packaging and conservation on the quality, nutritional and microbiological of sorghum cookies fortified with moringa and Spirulina. Journal of Applied Biosciences 109: 1056110570.

23. Karar MM, Sorto M, Tidjani A (2016) Caractéristiques nutritionnelles du Dihé traditionnel et amélioré, algue bleu-vert du Lac Tchad. Revue Scientifique du Tchad - Série spéciale - mai 2016 - Forum National sur la Nutrition et l'Alimentation p. 49-57.

24. Earthrise Farms Spirulina (1986) Product Typical Analysis. Earthrise Farms Spirulina, San Rafael, USA. In Falquet \& Hurni JP (2006) Spiruline : aspects nutritionnels. Antenna Technologies, p. 41.

25. Vermorel M, Toullec G, Dumond D, Pion R (1975) Valeur énergétique et protéique des algues bleues spirulines supplémentées en acides amines. AnnNutr Aliment 29: 535-552.

26. Butler MJ, Day AW (1998) Fungal melanins : a review. Canadien Journal Microbiology, 44(12): 1115-1136.

27. Chapeland-Leclerc F, Papon N, Noël T, Villard J (2005) Moisissures et risques alimentaires (mycotoxicoses). Revue Française des Laboratoires, pp. 373.

\section{Your next submission with Juniper Publishers will reach you the below assets}

- Quality Editorial service

- Swift Peer Review

- Reprints availability

- E-prints Service

- Manuscript Podcast for convenient understanding

- Global attainment for your research

- Manuscript accessibility in different formats

( Pdf, E-pub, Full Text, Audio)

- Unceasing customer service

Track the below URL for one-step submission

https://juniperpublishers.com/online-submission.php 